\title{
Correction to: Immigration Policies and Immigrant Women's Vulnerability to Intimate Partner Violence in Canada
}

\section{Vathsala Jayasuriya-Illesinghe ${ }^{1}$}

\section{Correction to: Int. Migration \& Integration https://doi.org/10.1007/s12134-018-0545-5}

The original version of this article unfortunately contained an error.

On page 3, last paragraph, we say "The 10-year sponsorship agreement"; it should actually be "The 3-year sponsorship agreement."

The online version of the original article can be found at https://doi.org/10.1007/s12134-018-0545-5

Vathsala Jayasuriya-Illesinghe vathsalai@ryerson.ca

1 Yeates School of Graduate Studies, Ryerson University, 350 Victoria St, Toronto, ON M5B 2K3, Canada 